\title{
FIRST REPORT OF A HUMAN CASE OF POLYCYSTIC ECHINOCOCCOSIS DUE TO Echinococcus vogeli FROM NEOTROPICAL AREA OF PERU, SOUTH AMERICA
}

\begin{abstract}
SUMMARY
We report a human case of polycystic hidatidosis due to Echinococcus vogeli from Contamana (Department of Loreto) village located in the central jungle of Peru. The patient is a 44 year-old lady, teacher, who carried a painless liver mass since a year ago. She was submitted to abdominal surgery and the liver mass was removed and showed multiple cysts containing colorless liquid as is showed in the polycystic hidatidosis. The morphology and measure of the hooks obtained from the liquid contained in the cysts are from Echinococcus vogeli. It is the first report of this parasitism in Perú.
\end{abstract}

KEYWORDS: E. vogeli; Human case; Perú.

\section{CASE REPORT}

A 44 year-old female schoolteacher, born in Contamana (Department of Loreto, in the jungle of Perú) who had lived only in the jungle region, was submitted to a routinary health control a year ago. A liver mass was detected by ultrasound, at that time no symptoms were present and she was sent to the Social Security Hospital "Edgardo Rebagliati" in Lima, capital of Perú, for further exploration and treatment.

The patient was asymptomatic on admittance, but her hepatomegaly was evident. The past clinical history was unimportant, except her contact with wild animals, which are often eaten in the jungle.

The CAT SKAN showed a mass with several cysts in the right area of the liver, containing several calcifications. Immunodiffusion using $E$. granulosus hydatid fluid (Arc V test) was negative.

The patient underwent adbominal surgery to remove the liver mass. The main findings were:

1. Polycystic hepatic tumor in segments I, IV, V, VI, VII and VIII of the liver.

2. Some of the cysts were infiltrating the inferior vena cava, the right diaphragm, the colon, peritoneum and omentum, and the left gastric curvature.

The hepatic tumor was removed by right hepatectomy. The tumor was made up of many 1-4 cm cysts, some of them confluent. Most cysts contained clear fluid but some had necrotic yellowish material, and a few presented calcified areas (Fig.1). The histological sections showed the presence of germinal membranes and protoscolices typical of a hydatid cyst (THOMPSON, 1995³; D’ ALESSANDRO, 1997¹).

The hooks were identified and measured at the Division of Parasitology of the Instituto Nacional de Salud del Perú (INS). The longer hooks measured 40 to $45 \mu \mathrm{m}$ and the shorter ones 28 to $35 \mu \mathrm{m}$ among 50 examined, according to KAMINSKY, $1996^{2}$ (Fig. 2).

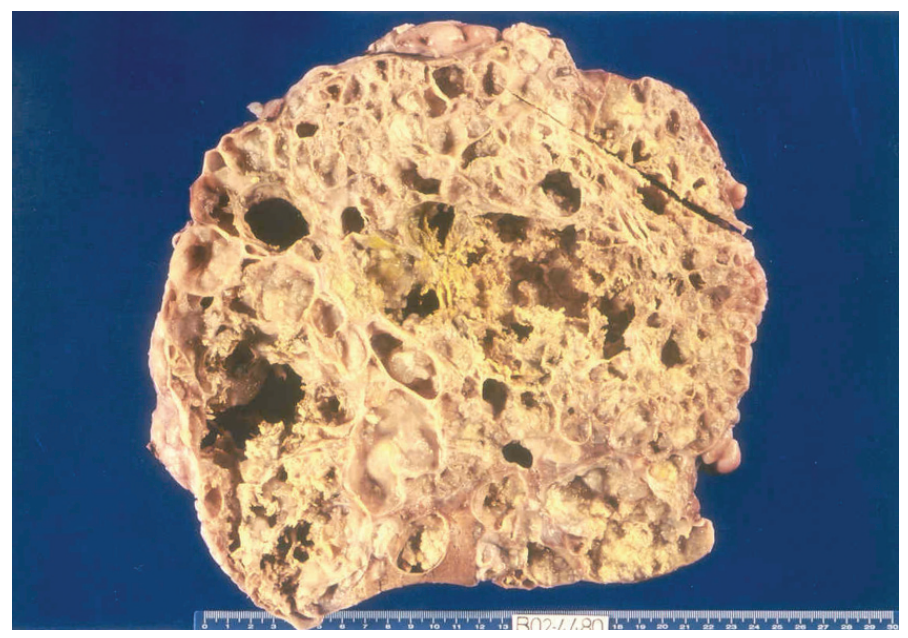

Fig. 1 - The hepatic cysts removed by surgery. 


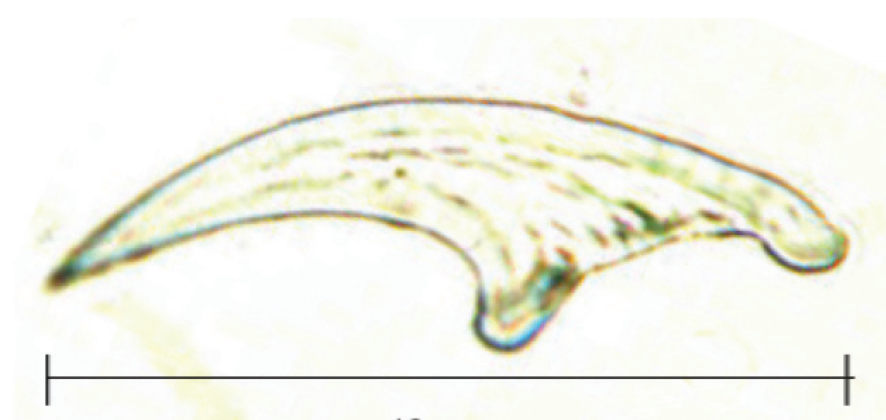

$43 \mu \mathrm{m}$

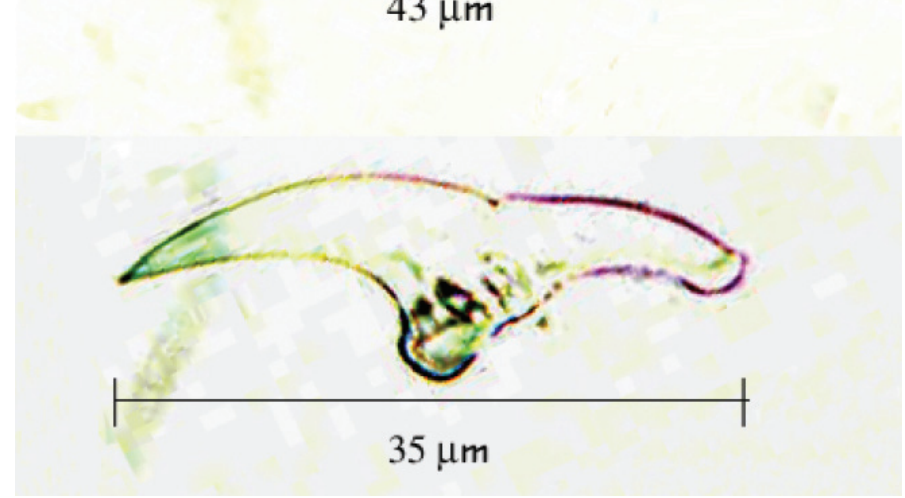

Fig. 2 - Hooks from the cysts belonging to Echinococcus vogeli.

The conclusion reached was that the infecting parasite was the larva of Echinococcus vogeli, which so far has not been described in Perú.

\section{RESUMEN}

Primer reporte de un caso humano de echinococcosis poliquística causada por $\boldsymbol{E}$. vogeli procedente del área neotropical del Perú,

\section{America del Sur}

Reportamos un caso humano de hidatidosis poliquística debido a Echinococcus vogeli procedente de Contamana (Departamento de Loreto), localidad ubicada en la selva central del Perú. La paciente es una mujer de 44 años de edad, profesora, quien portaba una hepatomegalia no dolorosa de un año de evolución. Sometida a intervención quirúrgica, se removió la masa hepática que macroscópicamente mostró múltiples quistes conteniendo líquido incoloro. El examen microscópico correspondió a una hidatidosis poliquística. El examen y medida de los ganchos obtenidos del contenido de los quistes correspondieron a Echinococcus vogeli. Es el primer reporte de este parasitismo en el Perú.

\section{REFERENCES}

1. D' ALESSANDRO, A. - Polycystic echinococcosis in tropical America: Echinococcus vogeli and Echinococcus oligarthrus. Acta trop. (Basel), 67: 43-65, 1997.

2. KAMINSKY, R.G. \& AUCEDA F.R. - Manual de Parasitología. Tegucicalpa, OPS/ OMS, 1996.

3. THOMPSON, R.C.A. - Biology and systematics of Echinococcus. In: THOMPSON, R.C.A. \& LYMBERY, A.J., ed. Echinococcus and hydatid disease. Wallingford, CAB International, 1995. p. 1-50.

Received: 20 August 2003

Accepted: 1 December 2003 